\title{
RANCANG BANGUN PROTOTYPE PEMBANGKIT LISTRIK TENAGA UAP MINI SEBAGAI MEDIA PRAKTIKUM MAHASISWA
}

\author{
Ahmad Yani ${ }^{1}$, Dedi Mustafa ${ }^{2}$, Taqwa ${ }^{3}$ \\ Jurusan Teknik Mesin Sekolah Tinggi Teknologi Industri Bontang ${ }^{1}$ \\ Jl. Brigjen Katamso No. 40, Bontang, Kalimantan Timur, Indonesia \\ Jurusan Teknik Mesin Universitas Trunajaya Bontang ${ }^{2,3}$ \\ Jl. Taekwondo No. 55, Bontang, Kalimantan Timur, Indonesia \\ Email: yanibima@gmail.com¹, dhedydhaen@gmail.com²,Takwavankuzuma25@gmail.com³
}

\begin{abstract}
Abstrak
Penelitian ini bertujuan untuk menghasilkan produk berupa prototype pembangkit listrik tenaga uap yang dapat digunakan untuk alat praktikum mahasiswa sehingga dapat meningkatkan pengetahuan dan kemampuan berpikir ilmiah mahasiswa dalam pembelajaran matakulaih konversi energi. Penelitian dilakukan melalui beberapa tahapan yaitu; perancangan dan pembuatan komponen-komponen mesin uap mini supaya bisa dirakit, perancangan instalasi mesin uap mini, dan pengujian prototype mesin uap mini. Berdasarkan hasil penelitian yang dilakukan, dapat disimpulkan bahwa prototype pembangkit listrik tenaga uap mini dapat menghasilkan energi listrik sebesar 0,15 Watt tanpa diberi beban lampu, sehingga bisa digunakan untuk media praktikum mahasiswa teknik mesin khususnya pada mata kuliah konversi energi.
\end{abstract}

Kata kunci: Rancang bangun, Prototype, Mesin uap, dan Media Praktikum.

\section{PENDAHULUAN}

Ketel uap adalah suatu alat yang digunakan untuk mengkonversikan air menjadi uap dengan cara pemanasan, dimana sumber panas tersebut berasal dari hasil pembakaran bahan bakar di ruang bakar [2]. Uap diproduksi dengan penggunaan secara langsung kalor yang dihasilkan dari pembakaran bahan bakar padat, cair, gas, kalor energi listrik ataupun energi nuklir. Pada proses kenaikan suhu atau pembakaran ini berdasarkan pada prinsip termodinamika dan perpindahan panas yang disebabkan perbedaan temperatur, dari temperatur rendah menuju temperatur tinggi [1].

Produksi uap harus dapat memenuhi kebutuhan pabrik, maka setiap komponen ketel uap harus berada dalam kondisi baik, untuk itu evaluasi terhadap prestasi kerja ketel uap perlu dilakukan, terutama untuk mengetahui efisiensi dari ketel uap tersebut [1].

Ketel uap (boiler) sebagai sumber energi proses merupakan sistem peralatan yang banyak digunakan pada industri kecil menengah hingga kelas power plant yang bergerak pada bidang pengolahan dan pembangkitan yang memproduksi uap (steam). Ketel uap merupakan suatu alat yang biasanya digunakan untuk proses perebusan atau memasak, sterilisasi, penyulingan, pengering dan sebagainya [3].

Penelitian pengembangan media pembelajaran juga sering dilakukan dalam upaya mencari solusi alternatif permasalahan dalam pembelajaran. Penggunaan media pembelajaran dalam proses belajar mengajar dapat membangkitkan keinginan dan minat yang baru, membangkitkan motivasi dan rangsangan kegiatan pembelajaran dan bahkan membawa pengaruh-pengaruh psikologis terhadap mahaiswa. Penggunaan media pembelajaran akan sangat membantu efektifitas proses pembelajaran serta penyampaian pesan dan isi pelajaran sehingga dapat membantu mahasiswa meningkatkan pemahaman karena 
menyajikan informasi secara menarik dan terpercaya [4].

Pelaksanaan kegiatan praktikum dilakukan dalam pemberian pengalaman belajar kepada mahasiswa, supaya mahasiswa dapat berinteraksi dengan bahan-bahan pelajaran dan pengamatan gejala secara langsung yang terjadi pada alat uji mesin uap mini tersebut. Kegiatan praktek di laboratorium dapat meningkatkan keterampilan mahasiswa apabila digunakan secara efisien, karena dengan praktek mahasiswa dapat memahami mata kuliah yang memerlukan penghayatan kongkrit dengan melakukan kegiatan nyata melalui praktek [5].

Pada penelitian ini penulis membuat prototype pembangkit listrik tenaga uap mini yang menggunakan bahan bakar gas LPG sebagai bahan bakar utama untuk mendidihkan air pada boiler mini (tabung freon) hingga menghasilkan uap. Uap yang dihasilkan dari proses mendidihnya disalurkan ke mesin uap untuk menggerakkan piston pada mesin uap mini melalui alat regulator dan hose yang terhubung dari boiler ke mesin uap mini yang selanjutnya akan memutar generator guna menghasilkan energi listrik.

\section{TINJAUAN PUSTAKA}

\section{Siklus Pembangkit Listrik Tenaga Uap (PLTU) Secara umum.}

Pembangkit listrik merupakan proses perubahan bentuk satu energi ke bentuk energi lain dimana sebagai produknya berupa energi listrik. PLTU mengubah energi kimia dari bahan bakar menjadi energi panas yang ditransfer ke air pengisi.

Bentuk / wujud energi diatas posisinya / keberadaannya seperti berikut:

a. Energ kimia, terdapat dalam bahan bakar.

b. Energi kalor, terjadi pada proses reaksi/ pembakaran, panasditeruskan ke dinding pipa ketel, diterima air ketel sebagai energikalor.

c. Energi kinetik, energi uap berubah fungsi kecepatan mendorong sudu memutar poros turbin.

d. Energi mekanik merupakan pemusatan energi yang terletak disumbu poros turbin.

e. Energi listrik, putaran poros turbin diteruskan ke poros generator menghasilkan listrik.

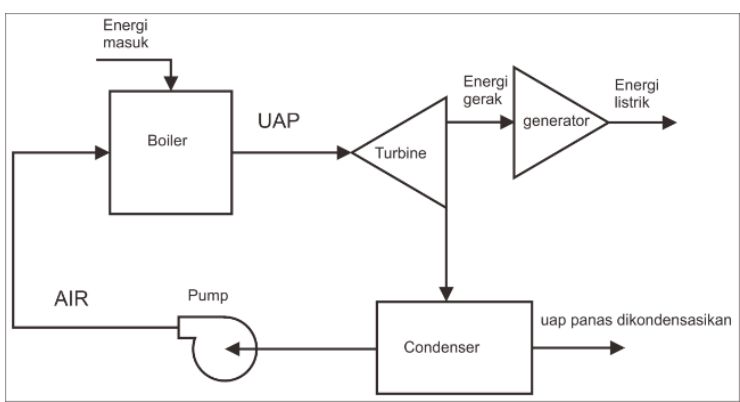

Gambar 1. Bagan Siklus PLTU Umum

Seperti diketahui untuk merealisasikan transformasi energi pada berbagai komponen utama PLTU, diperlukan fluida perantara yang disebut fluida kerja. Fluida kerja yang dipakai di PLTU adalah air. Sebagai perantara, fluida kerja akan mengalir melintasi beberapa komponen utama PLTU dalam suatu siklus tertutup, seperti tampak pada gambar 1. Selama melewati lintasan tertutup tersebut, fluida kerja mengalami perubahan wujud yaitu dari air menjadi uap untuk kemudian menjadi air kembali. Karena itu siklus fluida kerja dapat dipisahkan menjadi dua sistem, yaitu sistem uap dan sistem air [3].

\section{Siklus Pembangkit Listrik Tenaga Uap yang diteliti penulis.}

PLTU mengubah energi kimia dari bahan bakar menjadi energi panas yang ditransfer ke air pengisi sehingga menjadi energi kinetik pada uap yang kemudian uap tersebut digunakan untuk menggerakkan piston secara bolak balik, dari putaran poros crankshaft menggerakan generator sehingga menghasilkan energi listrik. Bentuk / wujud energi diatas posisinya / keberadaannya seperti berikut:

a. Energi kimia, terdapat dalam bahan bakar.

b. Energi kalor, terjadi pada proses reaksi/ pembakaran, panasditeruskan ke dinding pipa ketel, diterima air ketel sebagai energi kalor. 
c. Energi kinetik, energi uap berubah fungsi kecepatan mendorong piston memutar crankshaft.

d. Energi mekanik merupakan pemusatan energi yang terletak disumbu poros mesin uap.

e. Energi listrik, putaran poros mesin uap diteruskan ke poros generator menghasilkan listrik.

Bagan siklus PLTU mini yang diteliti penulis ditunjukkan pada gambar 2 .

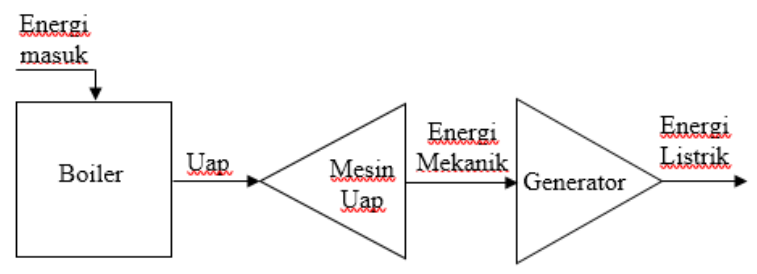

Gambar 2. Bagan Siklus PLTU Hasil Rancangan.

Daya yang dihasilkan dinamo adalah sama dengan hasil kali arus listrik dan tegangan yang dihasilkan oleh dinamo. Rumus daya output mesin uap mini seperti ditunjukkan pada persamaan berikut ini [6].

$$
P=V x I
$$

Dengan:

$$
\begin{array}{ll}
\mathrm{P} & =\text { Daya listrik (Watt) } \\
\mathrm{V} & =\text { Tegangan output dinamo (Volt) } \\
\mathrm{I} & =\text { Arus output (Ampere) }
\end{array}
$$

\section{METODE PENELITIAN}

Penelitian yang dilakukan menggunakan metode eksperimental dengan rancangan percobaan berskala mini menggunakan satu set up peralatan mesin uap mini. Penelitian ini bertempat di bengkel las bubut Wahyu dan di rumah penulis. Waktu penelitiannya dilakukan pada Bulan April 2018 dengan pengujian prototype mesin uap mini yang telah dibuat. Bentuk prototype mesin uap mini yang telah dibuat penulis seperti ditunjukkan pada gambar 3 .

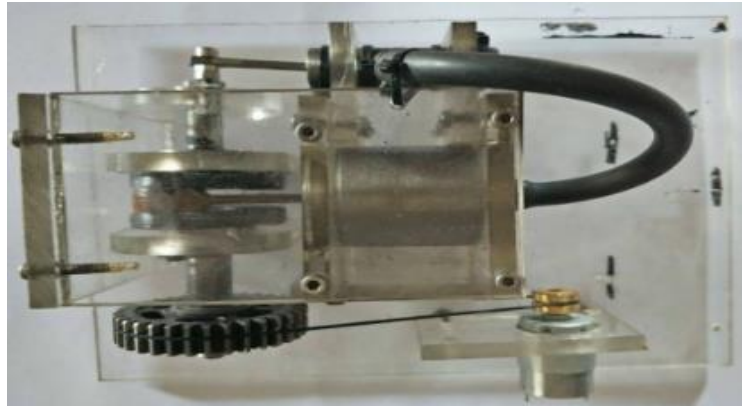

Gambar 3. Prototype mesin uap mini

\section{Prosedur Penelitian}

Adapun prosedur penelitian ini dibagi menjadi dua yaitu proses perancangan dan pembuatan prototype, dan proses pengujian prototype mesin uap mini. Prosedur pengambilan data penelitian yaitu sebagai berikut:

1. Membuat tabel untuk mencatat hasil pengujian.

2. Menyiapkan dan memasang semua instalasi penelitian beserta alat ukur yang digunakan.

3. Menyalakan kompor untuk memanaskan boiler hingga tekanan uap pada baoiler mencapai 60 Psi.

4. Melakukan pengambilan data tekanan uap pada boiler (konstan60 Psi / 4 Bar).

5. Melakukan pengambilan data temperatur uap.

6. Melakukan pengambilan data rpm mesin uap mini tanpa beban, dan dengan beban dinamo 12 Volt.

7. Melakukan pengambilan data tegangan dan arus listrik.

8. Mengolah data penelitian yang didapatkan.

9. Menganalisa data penelitian yang didapatkan untuk mengetahui hubungan antara variabel yang telah ditentukan.

10. Menarik kesimpulan dari hasil penelitian yang dilakukan.

\section{Instalasi Alat Penelitian}

Pada penelitian ini alat pengujian yang digunakan adalah mesin uap ini yang pembuatannya dan instalasinya dilakukan bengkel las bubut Wahyu dan di rumah penulis. Desain dan prototype serta instalasi mesin uap mini yang menjadi 
objek penelitian penulis seperti ditunjukkan pada gambar 4.

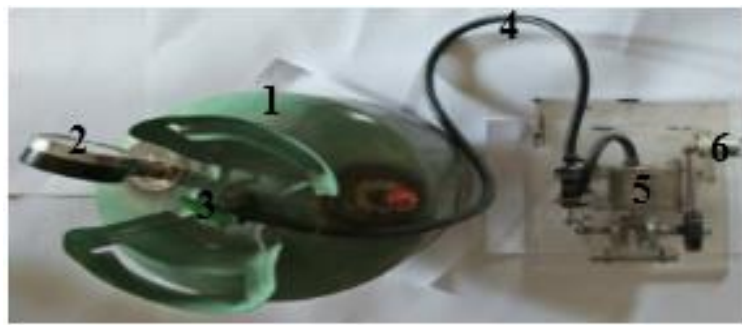

Gambar 4. Instalasi mesin uap mini.

Keterangan gambar instalasi penelitian mesin uap mini:

1. Boiler mini

2. Pressure gauge

3. Valve

4. Hose

5. Mesin uap mini

6. Dinamo

\section{HASIL DAN PEMBAHASAN}

\section{Data Hasil Penelitian}

Penelitian dengan melakukan perancangan dan pembuatan serta pengujian terhadap mesin uap mini di dapatkan hasil berupa sebuah set up mesin uap mini dan data hasil pengujian prototype mesin uang mini. Pengujian ini dilakukan untuk mendapatkan data tekanan uap $(\mathrm{P})$, temperature uap $(\mathrm{T})$, putaran mesin uap mini (rpm), tegangan (V), dan arus listrik (I). Sehingga diperoleh data penelitian seperti ditunjukkan pada tabel 1 dan tabel 2 .

Tabel 1. Data rerata pengujian tanpa beban

\begin{tabular}{|c|c|c|}
\hline $\begin{array}{c}\text { Tekanan } \\
\text { Uap }\end{array}$ & $\begin{array}{c}\text { Temperatur } \\
\text { Uap }\end{array}$ & $\begin{array}{c}\text { Putaran } \\
\text { mesin }\end{array}$ \\
\hline 60 Psi & $259,2^{\circ} \mathrm{C}$ & $1871,6 \mathrm{rpm}$ \\
\hline
\end{tabular}

Tabel 2. Data rerata pengujian dengan beban dinamo

\begin{tabular}{|c|c|c|c|c|}
\hline $\begin{array}{c}\text { Tek } \\
\text { ana } \\
\mathrm{n}\end{array}$ & $\begin{array}{c}\text { Tem } \\
\text { perat } \\
\text { ur }\end{array}$ & $\begin{array}{c}\text { Putara } \\
\mathrm{n} \\
\text { Uap }\end{array}$ & $\begin{array}{c}\text { Uap } \\
\text { Uesing } \\
\text { an } \\
\text { Listrik }\end{array}$ & $\begin{array}{c}\text { Arus } \\
\text { Listri } \\
\mathrm{k}\end{array}$ \\
\hline $\begin{array}{c}60 \\
\text { Psi }\end{array}$ & $\begin{array}{c}239,4 \\
{ }^{\circ} \mathrm{C}\end{array}$ & $\begin{array}{c}1612,2 \\
\mathrm{rpm}\end{array}$ & 12 Volt & $\begin{array}{c}12,5 \\
\mathrm{~mA}\end{array}$ \\
\hline
\end{tabular}

\section{Pembahasan Hasil Penelitian}

Berdasarkan tabel 1 dan tabel 2, rancang bangun prototype pembangkit listrik tenaga uap mini dapat beroperasi dengan baik dan dapat menghasilkan energi listrik dengan daya output sebesar 0,15 Watt tanpa diberi beban lampu. Selain itu prototype pembangkit listrik tenaga uap mini dapat mempermudah mahasiswa dalam memahami materi pembelajaran, serta dapat mengembangkan keterampilan proses sains dan juga dapat digunakan oleh dosen sebagai alat demonstrasi yang membantu dosen untuk mempermudah dan memperjelas penyampaian materi dan pesan pembelajaran mesin konversi energi.

\section{KESIMPULAN}

Berdasarkan hasil penelitian dan pembahasan, dapat ditarik kesimpulan bahwa prototype pembangkit listrik tenaga uap mini dapat menghasilkan energi listrik dengan daya output sebesar 0,15 Watt tanpa diberi beban lampu. Sehingga bisa digunakan untuk media praktikum mahasiswa teknik mesin khususnya pada matakuliah konversi energy dan mesin uap.

\section{REFERENSI}

[1]. Firdaus. A \& Sirait. E (2015). Analisa Pengaruh Variasi Kapasitas Uap Terhadap Efisiensi Ketel Uap Di Pt. Sinar Sosro BanyuasinSumatera Selatan. Jurnal Energi dan Manufaktur Vol 8, No 2. Jurusan Teknik Mesin, Universitas Sriwijaya. Sumatra Selatan.

[2]. Soedjono, Denny M. E; Sarsetyanto. Joko; Noor, Dedy. Z; \& Andriani. L. (2015). Kaji Numerik Ketel Uap Sederhana Berbahan Bakar LPG Pada Industri Kecil Tahu Menggunakan Program Ansys 14.0. Seminar Nasional Sains dan Teknologi Terapan ISBN 978-602-98569-1-0 Institut Teknologi Adhi Tama Surabaya 
[3]. Aqsha. B; Sarwoko. M,; \&

Kurniawan. E. (2015).

Realisasi Pembangkit Listrik

Mini Tenaga Sampah. e-

Proceeding of

Engineering:Vol.2,No.2.Jur

usanTeknikElektro

UniversitasTelkom.

Bandung.

[4]. Elfinurfadri. F; Rasyid. R; \&

Nasbey. H. (2013).

Pengembangan Miniatur

embangkit Listrik Tenaga

Uap Sebagai Media

Pembelajaran Fisika Sekolah

Menengah Atas (SMA).

Seminar Nasional Fisika

Universitas Negeri Jakarta.

[5]. Yani. A (2017). Rancang Bangun Alat Praktikum Turbin Air Dengan Pengujian Bentuk Sudu Terhadap Torsi Dan Daya Turbin Yang Dihasilkan. Jurnal Turbo No. 1 Volume 6. Jurusan Teknik Mesin Universitas Muhammadiyah Metro.

[6]. Yani. A (2016) Pengaruh penambahan alat pencari arah sinar matahari dan lensa cembung terhadap daya output solar cell. Jurnal Turbo Nomor 2. Volume 5. Jurusan Teknik Mesin Universitas

Muhammadiyah Metro. 